\title{
Denervation of three equivalent right renal arteries in a patient with resistant hypertension after left-sided nephrectomy: five-year follow-up
}

\author{
Aneta I. Gziut, Robert J. Gil \\ Department of Invasive Cardiology, Centre of Postgraduate Medical Education, Warsaw, Poland
}

Adv Interv Cardiol 2020; 16, 1 (59): 114-115 DOI: https://doi.org/10.5114/aic.2020.93920

In the majority of patients with resistant hypertension, increased activity of the sympathetic system is observed. Denervation of renal arteries (RDN) is one of the methods that may lead to reduction of blood pressure $[1,2]$. Although the ESC/ESH guidelines do not recommend using invasive methods in the routine treatment of hypertension, current Polish Society for Hypertension guidelines published after the SPYRAL and RADIANCE trial publications emphasise the effectiveness and benefits of this form of treatment [3, 4]. Currently, it is recommended that RDN is classified and performed only in highly specialised centres [3, 4].

A 62-year-old patient was admitted because of increased values of blood pressure (average blood pressure (BP) $170 / 100 \mathrm{~mm} \mathrm{Hg}$ ) despite taking five antihypertensive drugs in maximum doses: carvedilol, doxazosin, valsartan, hydrochlorothiazide, and nitrendipine. The patient's history included: left-sided nephrectomy because of renal cell carcinoma (15.03.2000), two strokes, type 2 diabetes, and obesity (body mass index (BMI) $45 \mathrm{~kg} / \mathrm{m}^{2}$ ). The reasons of secondary hypertension were excluded. Ambulatory blood pressure monitoring (ABPM) confirmed inappropriate control of BP (average 172/96 mm Hg: day average 179/102 mm Hg, night average 156/83 mm $\mathrm{Hg}$ ). An angio-computed tomography (CT) scan revealed three separate, equivalent arteries supplying blood to the right kidney (Figures $1 \mathrm{I}$, II). The arteries ran parallel in the proximal and medial parts (the upper artery - length $83 \mathrm{~mm}$, diameter $4.5 \mathrm{~mm}$, the lower $85 \mathrm{~mm}$ and $4.3 \mathrm{~mm}$, the medial $110 \mathrm{~mm}$ and $4.0 \mathrm{~mm}$, respectively). The patient was qualified for RDN. The denervation was performed in three right arteries with the use of a multielectrode catheter EnligHTN ${ }^{\top M}$ (St. Jude Medical). In every artery two radiofrequency applications were done (eight ablation points altogether) (Figure $1 \mathrm{III}$ ).
The pharmacological treatment was maintained throughout the follow-up period. During control visits after 1 and 6 months the patient had satisfactory control of BP (mean BP 136/77 mm Hg, 124/65 mm Hg, respectively), and no episodes of hypotension were observed nor biochemical features of deterioration of kidney function. Seven months after RDN the patient was admitted to the hospital because of a collapse. Low BP values were found on admission (90/45 $\mathrm{mm} \mathrm{Hg}$ ); biochemical test results showed no abnormalities. ABPM revealed low BP values (day 105/56 mm Hg, night 111/59 mm Hg). The doses of antihypertensive drugs were reduced, with normal BP values observed. One year after the procedure ABPM showed a day average of 150/87 mm Hg and night average of $137 / 70 \mathrm{~mm} \mathrm{Hg}$. The drug dose was then increased. During subsequent outpatient check-ups 2 and 3 years after denervation good control of blood pressure was observed (mean BP 139/74 mm Hg, 137/80 mm Hg, respectively). However, during the check up after 4 and 5 years increased BP values were observed again (day average 150/95 mm Hg, night average 142/90 mm Hg). No deterioration of kidney function in lab tests and ultrasonography exam was observed. The antihypertensive drug doses were increased again.

In the beginning of application RDN was performed only in patients with good renal function and renal arteries without atherosclerotic lesions. In subsequent studies, RDN was performed also in patients with more complex anatomy of renal circulation $[4,5]$. The described patient is a representative of such population. RDN in three arteries supplying blood to the solitary kidney had no complications. Immediately after the procedure BP was significantly reduced. The full antihypertensive effect was observed more than 3 years after RDN. Unfortunately, after 3 years the BP values increased, requiring

\section{Corresponding author:}

Aneta I. Gziut MD, PhD, Department of Invasive Cardiology, Centre of Postgraduate Medical Education, 137 Wołoska St, 02-507 Warsaw, Poland, phone: +48 607077 871, e-mail: anetagziut@poczta.onet.pl

Received: 13.09.2019, accepted: 5.12.2019. 


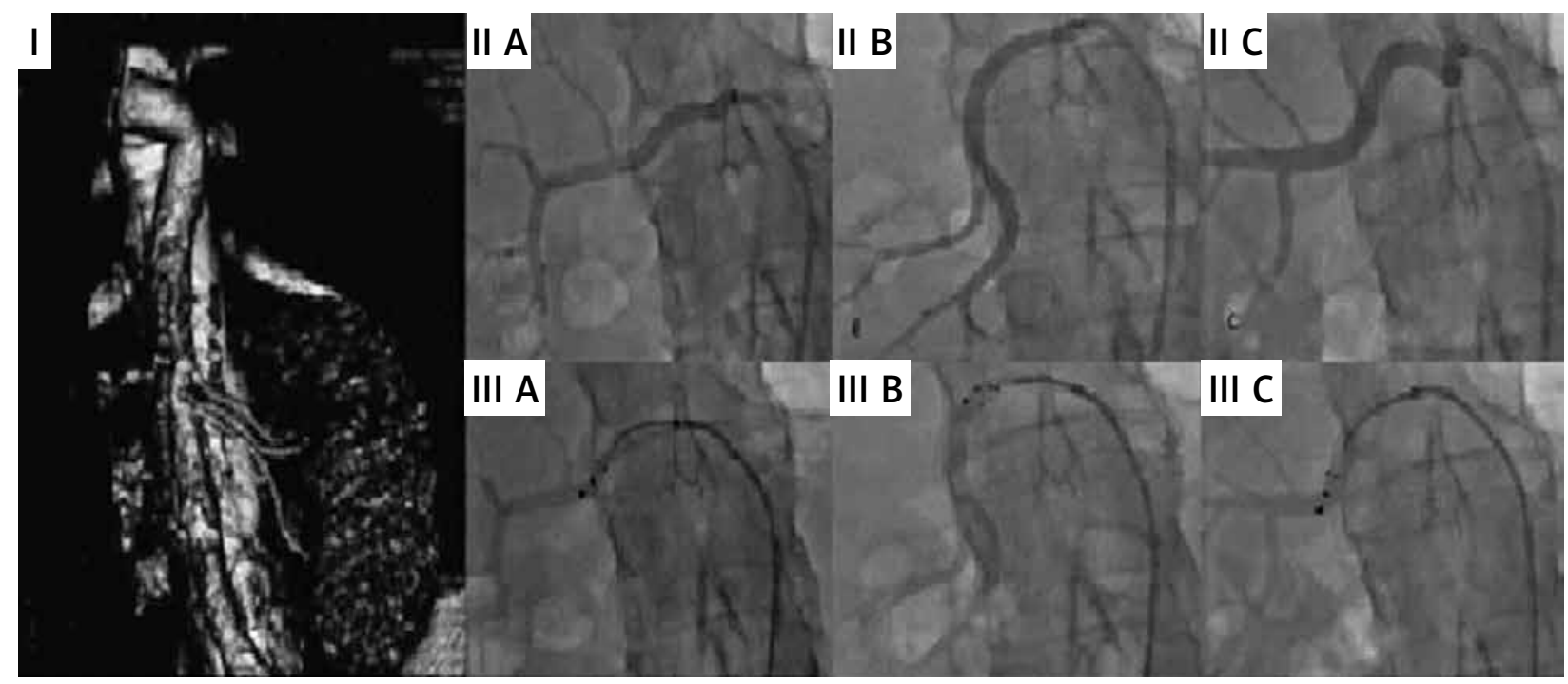

Figure 1. Three equivalent arteries leading to the right kidney in CT-scan (I) angiography (II) and renal denervation in separate arteries (III). A - upper, B - lower, C - medial

intensification of the antihypertensive treatment. This might have resulted from the rebuilding of afferent fibres in the renal arteries.

\section{Conflict of interest}

The authors declare no conflict of interest.

\section{References}

1. Calhoun DA, Jones D, Textor S, et al. Resistant hypertension diagnosis, evaluation, and treatment. A scientific statement from the American Heart Association Professional Education Committee of the Council for High Blood Pressure Research. Hypertension 2008; 51: 1403-19.

2. Mancia G, De Backer G, Dominiczak A, et al. 2007 Guidelines for the management of arterial hypertension of the European Society of Hypertension (ESH) and of the European Society of Cardiology (ESC). J Hypertens 2007; 25: 1105-87.

3. Williams B, Mancia G, Spiering W, et al. 2018 ESC/ESH Guidelines for the management of arterial hypertension. Eur Heart J 2018; 39: 3021-104.

4. Tykarski A, Filipiak KJ, Januszewicz A, et al. Zasady postępowania w nadciśnieniu tętniczym - 2019 rok. Wytyczne Polskiego Towarzystwa Nadciśnienia Tętniczego. Nadciśnienie Tętnicze w Praktyce 2019; 5: 1-86.

5. Kądziela J, Warchoł-Celińska E, Prejbisz A, et al. Renal denervation - can we press the "ON" button again? Adv Interv Cardiol 2018; 14: 321-7. 